\title{
Dietary assessment methodology for adolescents: a review of reproducibility and validation studies
}

${ }^{a}$ Rankin D, PPD, RD(SA), PhD(Nutr) a Hanekom SM, RD(SA), PhD(Nutr) a Wright HH, RD(SA), PhD(Dietetics) ${ }^{\circ}$ Maclntyre UE, PhD(Nutr) ${ }^{a}$ School of Physiology, Nutrition and Consumer Science, North-West University, South Africa ${ }^{\mathrm{b}}$ Institute for Human Nutrition, University of Limpopo (Medunsa Campus), South Africa Correspondence to: Dr SM Hanekom, e-mail: grieta.hanekom@nmu.ac.za Keywords: dietary assessment methods; reproducibility; validity; adolescents

\section{Abstract}

Aim: The aim of this review is to explore the validity and/or reproducibility of dietary assessment methods used to assess food and nutrient intakes of adolescents.

Method: A detailed literature search was undertaken to trace articles reporting on the validity and/or reproducibility of food records, food frequency questionnaires (FFQs) and 24-hour recalls for the dietary assessment of adolescents, especially among South Africans, in the following databases: Medline, Science Direct, Academic Search Premier, Health Source, PubMed and the South African e-publications database (SAE). Original studies published between 1990 and 2009, and relevant original articles published before 1990, were included. Of these, only three were South African-based studies reporting testing for reproducibility and/or validity.

Results: Results indicated that adolescents comply better with estimated food records than with weighed food records. However, energy intake was underestimated in adolescents (by 18-42\%) when using food record methods. The relative validity of FFQs among adolescents was moderate, with correlation coefficients of $>0.3$ for most measured nutrients and food items. Reproducibility was fair to good among female adolescents (0.3-0.83) for most nutrients and foods, but was lower in a South African Tswana-speaking group. The 24-hour recall method showed the least over- and underestimation of all the reviewed methods. When comparing the 24-hour recall method to an observed intake method among adolescents, $<11 \%$ underestimation of energy intake was found, while $<4 \%$ underestimation was found when the 24 -hour recall method was tested against the doubly labelled water method.

Conclusion: Based on these outcomes it was concluded that FFQs and 24-hour recalls are valid and reproducible dietary assessment methods that can be used when collecting dietary data from adolescents. Factors to consider when choosing the best suitable method should include the gender and ethnicity of the population as well as the time frame for the collection of dietary data.

(P) Peer reviewed. (Submitted: 2009-12-20, Accepted 2010-04-24). ๑ SAJCN

S Afr J Clin Nutr 2010;23(2): 65-74

\section{Background}

Adolescence is one of the most challenging periods in human life. This period is characterised by rapid growth and increased hormone production, which affects all organs of the body, including the brain. During this period optimal nutrition is crucial to sustain normal growth and development. ${ }^{1,2}$ Adolescence is, however, also associated with the increased need to be independent and to be accepted by peers, which often has a negative impact on food choices and nutrient intake. Dietary data of adolescents are therefore valuable to dieticians and nutritionists in the evaluation of a specific individual, group or population's nutritional status to identify those at risk of nutrient deficiencies or chronic diseases of lifestyle. ${ }^{3-7}$ The accurate assessment of dietary intakes among adolescents, as for any other age group, remains a challenge, with various strengths, limitations and practical aspects to consider for each dietary assessment method.

A limited number of dietary assessment instruments specifically designed for adolescents have been found to be reproducible and valid. ${ }^{8}$ Reproducibility of a dietary assessment method reflects the ability of the method to obtain identical results when administered again at a later stage under similar circumstances. ${ }^{9}$ Validity reflects the ability of a dietary method to accurately measure what the participants have actually eaten. ${ }^{10}$ Dietary methods designed to characterise usual intakes of individuals are the most difficult to validate, since the "truth" is never known with absolute certainty. ${ }^{11}$ Relative validity, in which a new method (i.e. test method) is compared with an existing method known to be valid (i.e. reference method), is the most practical validation method to use. Absolute validity implies that the reference method reflects the true dietary intake, while relative validity recognises that the reference method itself is subject to error. ${ }^{10}$ Therefore, the extent of agreement between the test and reference methods is used to indicate the relative validity of the test method and the extent to which the reference method is believed to yield the truth. The use of biomarkers, such as urinary nitrogen, is a more objective approach to assess the validity of dietary intake data. These methods may however be expensive and impractical (for example, the collection of 24-hour urine samples) and are therefore often not used for validation purposes. ${ }^{10}$ 
The purpose of this review is to explore the validity and/or reproducibility of dietary assessment methods used to assess dietary intakes of adolescents. As background, the authors will provide a brief discussion of the various dietary assessment methods available (see Figure 1). For the purpose of this review an adolescent is defined as someone aged between 10 and18 years.

\section{Methods}

A detailed literature review was undertaken to find articles reporting on the validity and/or reproducibility of food records, food frequency questionnaires (FFQs) and 24-hour recalls for dietary intake assessment in adolescents, especially South Africans. International journal databases such as Medline, Science Direct, Academic Search Premier, Health Source, PubMed and the South African e-publications database (SAE) were searched. The literature search was done for the period 1990-2009, using the following keywords: "adolescents", "validity", "reproducibility", "reliability", "food records", "food frequency questionnaire", "FFQ", "24hour recalls" and "dietary assessment". Relevant original studies published prior to 1990 were also included in this review. Reference lists of articles obtained were reviewed to identify additional relevant studies.

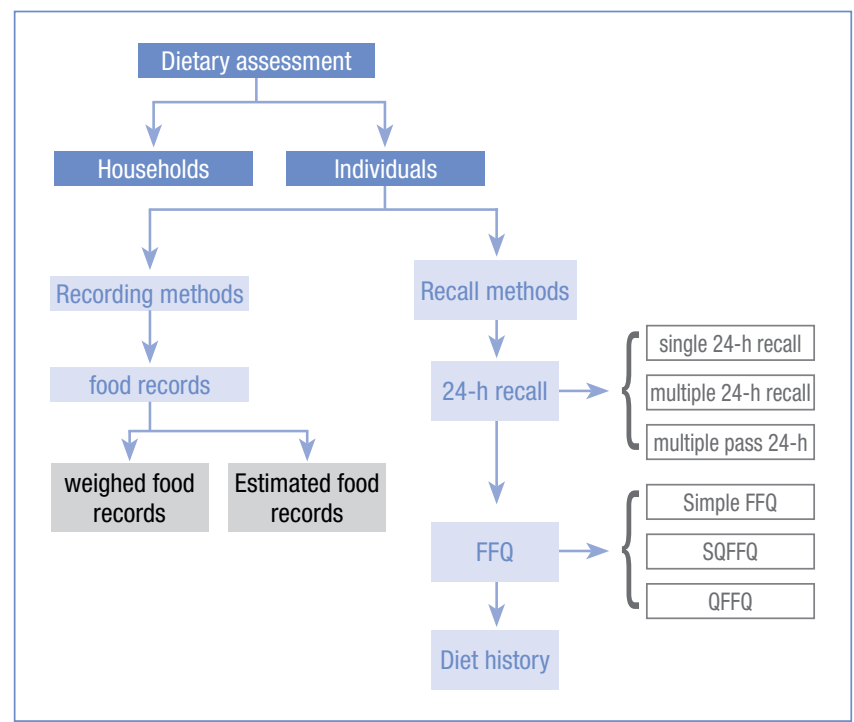

Figure 1: Dietary assessment methods

FFQ: food frequency questionnaire

SQFFQ: semi-quantitative food frequency questionnaire

QFFQ: quantitative food frequency questionnaire

\section{Results}

\section{Weighed and estimated food records}

Food records seem to be the golden standard dietary assessment method in adolescents since the researcher is not dependant on the memory of the participant or his/her ability to accurately recall portion sizes. For the same reason food records have been used as a reference method to determine the relative validity of other dietary assessment methods. However, the subject burden is high, especially with long food recording periods.

In Table I food records are described in terms of what they entail, how they are executed, and their strengths and limitations. Food records can be divided into either weighed food records (WFRs) or estimated food records (EFRs). The ideal time frame for keeping a food record is difficult to estimate. One needs to consider participant burden on the one hand and the number of recording days needed to get a representative picture of usual dietary intake on the other. ${ }^{12}$ Moreno et al ${ }^{8}$ found that under-reporting increased from one (7.9\%) to seven days (15.5\%) of recording among adolescents. This could be ascribed to a decrease in motivation over time or possibly initial over-reporting gradually returned to adequate reporting towards the end of the recording period. The burden of constantly weighing food/beverages has been shown to result in changes to usual intake in order to simplify weighing and recording. ${ }^{13}$ Chinnock ${ }^{14}$ found an unspecified weight loss in 60 adult subjects (30 rural men and women; 30 urban men and woman) after two weeks of keeping WFRs. The reason for this may be that when attention is paid to food intake people unconsciously or consciously tend to consume less, perhaps to lose weight or to avoid having to record food. ${ }^{14}$ Various studies show a three-day record to be a better estimation of nutrient intake than a one-day record or that non-consecutive days should be used when multiple records are used..$^{8-14,15,16-17}$ Nevertheless, researchers should keep in mind that true dietary intake may not be reflected by food records since participants are more aware of what they eat, which might result in different food choices.

The study by Kersting et $\mathrm{al}^{18}$ is an example of the use of WFRs to assess energy and nutrient intakes of children and adolescents (1-18 years) as part of the Dortmund Nutritional and Anthropometric Longitudinally Designed (DONALD) study done in Germany. ${ }^{19}$ Threeday WFRs (using an electronic food scale) were compiled. Younger children were assisted by their parents while older children and adolescents weighed and reported their own food intakes. If subjects were not able to weigh their food, household measures and the number of portions were also accepted.

\section{Validity of food records}

While food records are often used as a reference method for the determination of the relative validity of other dietary assessment methods; ${ }^{22-23,34-37}$ few studies report on the validity and reproducibility of food records themselves. In Table II studies reporting on the validity of food records among adolescents are summarised. No reproducibility data for these studies were available.

The use of doubly-labelled water (DLW) as an objective means of determining energy expenditure provides an independent measure of validity of reported energy intakes..$^{38}$ Studies comparing energy intake assessed by WFRs with energy expenditure estimated by the DLW method have shown an underestimation of energy intakes in adults ${ }^{39,40}$ and a more marked underestimation in adolescents. In nine studies that used food records to estimate energy and nutrient intakes among adolescents, ${ }^{14-15,38-44}$ the estimated energy intake expressed as a percentage of energy expenditure measured by DLW was between $82 \pm 21 \%$ and $89 \pm 12 \%$ for adolescents $\leq 12$ years, and $78 \pm 18 \%$ and $58 \pm 17 \%$ for $15-18$ year olds. Thus underestimation of energy intake by food records occurred in all of the studies and seemed to increase with age. Furthermore, the underestimation was independent of whether younger adolescents were aided by parents/dieticians or whether they kept the food records themselves. Possible factors contributing to underestimation among adolescents include: forgetting food items eaten away from 
Table I: The description, execution, strengths, and limitations of various dietary assessment methods

\begin{tabular}{|c|c|c|c|c|c|}
\hline \multicolumn{2}{|c|}{ Dietary method } & \multirow{2}{*}{$\begin{array}{l}\text { Description } \\
\text { Participant records all foods, } \\
\text { beverages, and/or recipes of food } \\
\text { items consumed over a given } \\
\text { period of time. }\end{array}$} & \multirow{2}{*}{$\begin{array}{l}\text { Execution } \\
\text { Non-consecutive random } \\
\text { days or consecutive days are } \\
\text { recommended. }\end{array}$} & \multirow{2}{*}{$\begin{array}{l}\text { Strengths } \\
\text { Errors due to dependence on the } \\
\text { participant's memory and accuracy } \\
\text { of recalling portion sizes are } \\
\text { minimised with both the following } \\
\text { methods. }\end{array}$} & \multirow{2}{*}{$\begin{array}{l}\text { Limitations } \\
\text { Participant burden is high in both } \\
\text { methods. }\end{array}$} \\
\hline & $\begin{array}{l}\text { Food records } \\
\text { (FRs) })^{4-5,9,15,19-23}\end{array}$ & & & & \\
\hline 1.1 & Weighed FRs ${ }^{14}$ & $\begin{array}{l}\text { Exact quantities of food items and } \\
\text { beverages are recorded in grams. }\end{array}$ & $\begin{array}{l}\text { Participant weighs all foods and } \\
\text { beverages before consumption and } \\
\text { leftovers after the meal/snack, on } \\
\text { a food scale }\end{array}$ & $\begin{array}{l}\text { Accurate recording of actual } \\
\text { amounts of food/beverage } \\
\text { consumed. }\end{array}$ & $\begin{array}{l}\text { Participant may change usual } \\
\text { dietary intakes in order to } \\
\text { decrease/simplify weighing of } \\
\text { foods/beverages. }\end{array}$ \\
\hline 1.2 & Estimated FRs ${ }^{14}$ & $\begin{array}{l}\text { Household measurements, food } \\
\text { models and/or food portion } \\
\text { photographs are used to estimate } \\
\text { amounts of foods and beverages } \\
\text { consumed. Estimates are } \\
\text { converted to grams. }\end{array}$ & $\begin{array}{l}\text { Participant estimates food } \\
\text { and beverage portions before } \\
\text { consumption. }\end{array}$ & $\begin{array}{l}\text { Less expensive. } \\
\text { Less subject burden than weighed } \\
\text { FR. }\end{array}$ & $\begin{array}{l}\text { Errors in conversion to grams can } \\
\text { occur. }\end{array}$ \\
\hline 2. & $\begin{array}{l}\text { Food frequency } \\
\text { questionnaires } \\
(\text { FFQs })^{5,15,24-29}\end{array}$ & $\begin{array}{l}\text { A list of questions on foods to } \\
\text { which the participant responds by } \\
\text { reporting the frequencies (number } \\
\text { of times) and amounts (portion } \\
\text { sizes) of the foods consumed per } \\
\text { day, per week or per month. }\end{array}$ & $\begin{array}{l}\text { Self-administered or administered } \\
\text { by interviewer. }\end{array}$ & $\begin{array}{l}\text { Good participant response rate. } \\
\text { Low in cost. } \\
\text { Good representation of usual } \\
\text { dietary intake. } \\
\text { Can be used in populations with } \\
\text { low literacy levels. }\end{array}$ & $\begin{array}{l}\text { Reduced accuracy in estimating } \\
\text { quantities of foods consumed. } \\
\text { Reliance on memory of participant. } \\
\text { Must be culturally sensitive to } \\
\text { avoid under-reporting. }\end{array}$ \\
\hline 2.1 & $\mathrm{QFFQS}^{1}$ & $\begin{array}{l}\text { Food and beverage portion sizes } \\
\text { are quantified in terms of grams or } \\
\text { millilitres. }\end{array}$ & $\begin{array}{l}\text { Administered by trained } \\
\text { interviewer with food models } \\
\text { and/or food photograph books to }\end{array}$ & $\begin{array}{l}\text { Best indication of estimated } \\
\text { portion sizes of FFQs. }\end{array}$ & \\
\hline 2.2 & SQFFQS ${ }^{30}$ & $\begin{array}{l}\text { Portion sizes of foods and } \\
\text { beverages typically consumed } \\
\text { are estimated in terms of small, } \\
\text { medium or large. }\end{array}$ & & $\begin{array}{l}\text { Easier to administer and lower } \\
\text { respondent burden than QFFQs. }\end{array}$ & \\
\hline 3. & $\begin{array}{l}\text { 24-hour recall } \\
\text { method }^{5,9,31,32,33}\end{array}$ & $\begin{array}{l}\text { Participant report all foods and } \\
\text { beverages consumed during the } \\
\text { previous } 24 \text {-hours. }\end{array}$ & $\begin{array}{l}\text { Administered by trained } \\
\text { interviewer with food models and/ } \\
\text { or food photograph books and/ } \\
\text { or household measurements to } \\
\text { estimate quantities. }\end{array}$ & $\begin{array}{l}\text { Quick method to assess usual } \\
\text { intake. } \\
\text { Suitable for use in populations with } \\
\text { low literacy levels. } \\
\text { Low respondent burden. } \\
\text { Good response rate. } \\
\text { Relatively low administration costs. }\end{array}$ & $\begin{array}{l}\text { Reliance on participant's memory } \\
\text { and ability to recall portion sizes, } \\
\text { which could lead to recall bias. } \\
\text { Subjective to socially desirable } \\
\text { responding. } \\
\text { Might not be representative of } \\
\text { participant's usual dietary intake. }\end{array}$ \\
\hline
\end{tabular}

home, lack of compliance to weigh all food items consumed, and failure to record all food/beverages consumed due to irritation and/ or boredom. ${ }^{31}$

It can therefore be concluded that WFRs do not seem to be a valid measure of energy intake of adolescents. A possible solution to this problem is suggested by Hise et al, namely that trained observers recorded and weighed fixed meals only, while participants completed a 24-hour snack recall for in-between meal snacks and meals eaten away from home. ${ }^{45}$ These combined observer-recorded WFRs and 24 -hour snack recalls showed a $99.4 \pm 17.9 \%$ accuracy for energy intake when compared with energy expenditure as tested by the DLW method. ${ }^{45}$

The relative validity of EFR has been investigated using a WFR as reference method. ${ }^{13,46}$ When mean estimates of energy, macronutrient and micronutrient intakes derived from the EFR were compared to intakes derived from WFRs, no significant differences were found. It appears therefore that the relative validity of EFRs is satisfactory and that EFRs can be used instead of WFRs when one is concerned about compliance and motivation of the study population to keep weighed food records. ${ }^{47}$

\section{Other determinants that influence the validity of food records}

The validity of food records may also be influenced by several other factors, including gender, age and body mass index (BMI) of the participants. Karvetti and Knuts ${ }^{48}$ found no differences in the relative validity of a two-day EFR (when compared to observed food intakes) between gender and age groups. Contrary to this, Bandini et $\mathrm{a}^{38}$ indicated that the accuracy of reported energy intake in girls declined longitudinally with age, while Champagne et al ${ }^{42}$ found that girls underestimated energy intake by $27 \%$ and boys by slightly less at $24 \%$.

When BMI was taken into account, Bandini et al ${ }^{13}$ and Kruger et al ${ }^{37}$ found that average reported energy intake (TEE, percentage of total energy expenditure ) was significantly lower in obese (58 $\pm 23.6 \%)$ than in non-obese $(80.6 \pm 18.7 \%)$ groups. Underreporting of energy 
Table II: Validity of food records

\begin{tabular}{|c|c|c|c|c|}
\hline Author & $\begin{array}{l}\text { Dietary assessment } \\
\text { method }\end{array}$ & Sample size & $\begin{array}{l}\text { Validated? } \\
\text { Reference method }\end{array}$ & Results \\
\hline $\begin{array}{l}\text { Bandini et al }{ }^{41} \\
1990\end{array}$ & $\begin{array}{l}\text { Estimated food record } \\
\text { ( } 2 \text { weeks): food models, } \\
\text { measuring cups and spoons }\end{array}$ & $\begin{array}{l}\text { Boys and girls, } \\
12-18 \mathrm{yr} \\
\text { non-obese }(n=28) \\
\text { obese }(n=27)\end{array}$ & $\begin{array}{l}\text { Absolute validity, total } \\
\text { energy expenditure (TEE) } \\
\text { by doubly-labelled water } \\
\text { (DLW) }\end{array}$ & $\begin{array}{l}\text { Reported energy intake (REI) was similar in obese and non-obese } \\
\text { adolescents but significantly lower than TEE in both groups } \\
\text { ( } p<0.0001) \text {. } \\
\text { REI as percentage of TEE was significantly lower in obese } \\
(58 \pm 23.6 \%) \text { than non-obese }(80.6 \pm 18.7 \%, p<0.001) \\
\text { adolescents, but similar between gender groups. }\end{array}$ \\
\hline $\begin{array}{l}\text { Livingstone et al }{ }^{12} \\
1992\end{array}$ & $\begin{array}{l}\text { Energy intake from weighed } \\
\text { food record (El-WFR) } \\
\text { (7 days) }\end{array}$ & $\begin{array}{l}12 \text { yr } n=12 \\
15 \text { yr } n=12 \\
18 \text { yr } n=10\end{array}$ & $\begin{array}{l}\text { Absolute validity, TEE by } \\
\text { DLW }\end{array}$ & $\begin{array}{l}\text { Energy intakes in } 12,15 \text { and } 18 \text { year olds showed an average } \\
\text { TEE of } 89 \pm 12 \%, 78 \pm 18 \% \text { and } 73 \pm 25 \% \text {, respectively. } \\
\text { El-WFR was less than TEE in } 29 \text { of } 34 \text { subjects. } \\
\text { The bias was at } \geq 20 \% \text { in } 13 \text { of the subjects and reached } 50 \% \text { in } \\
5 \text { of them. }\end{array}$ \\
\hline $\begin{array}{l}\text { Bandini et al }{ }^{13} \\
1997\end{array}$ & $\begin{array}{l}\text { Estimated food record } \\
\text { ( } 7 \text { days): food models, } \\
\text { measuring cups and spoons }\end{array}$ & $\begin{array}{l}\text { White and black, } \\
\text { Hispanic and other } \\
\text { ethnic girls } \\
(\mathrm{n}=109) \\
8-12 \mathrm{yr}\end{array}$ & $\begin{array}{l}\text { Absolute validity, TEE by } \\
\text { DLW }\end{array}$ & $\begin{array}{l}\text { Mean REI was } 13 \% \text { lower than TEE from DLW. Age was } \\
\text { significantly related to reporting accuracy, with underestimation } \\
\text { of energy intake from food records increasing with age. } \\
\text { There were no significant differences by ethnicity. } \\
\text { Adult help was required for the completion of records. }\end{array}$ \\
\hline $\begin{array}{l}\text { Bratterby et al }{ }^{44} \\
1998\end{array}$ & $\begin{array}{l}\text { Weighed food record } \\
\text { (7 days) }\end{array}$ & $\begin{array}{l}\text { Adolescent boys and } \\
\text { girls }(n=50) \\
15 \mathrm{yr}\end{array}$ & $\begin{array}{l}\text { Absolute validity, TEE by } \\
\text { DLW }\end{array}$ & $\begin{array}{l}\text { El of boys was } 81.9 \% \text { and of girls was } 78.3 \% \text { of TEE - an average } \\
\text { of } 20 \% \text { underestimation. }\end{array}$ \\
\hline $\begin{array}{l}\text { Champagne et al }{ }^{42} \\
1998\end{array}$ & $\begin{array}{l}\text { Food record } \\
\text { (8 days) }\end{array}$ & $\begin{array}{l}\text { Adolescents } \\
(\mathrm{n}=111) \\
10-12 \mathrm{yr}\end{array}$ & $\begin{array}{l}\text { Absolute validity, TEE by } \\
\text { DLW }\end{array}$ & $\begin{array}{l}\text { Mean REI was underreported by } 22.1 \pm 1.6 \% \text { for } 10 \text {-year-olds, } \\
20.3 \pm 3.2 \% \text { for } 11 \text {-year olds and } 32.8 \pm 4.9 \% \text { for } 12 \text {-year-olds. } \\
\text { Parent or guardian and a school nutritionist participated in the } \\
\text { record-keeping process. }\end{array}$ \\
\hline $\begin{array}{l}\text { Green et al }{ }^{43} \\
1998\end{array}$ & $\begin{array}{l}\text { Weighed food record } \\
\text { ( } 3 \text { days) }\end{array}$ & $\begin{array}{l}\text { Adolescent girls } \\
(\mathrm{n}=105), \\
16-19 \mathrm{yr}, \\
\text { supplement vs. non- } \\
\text { supplement users }\end{array}$ & $\begin{array}{l}\text { Absolute validity, } \\
\text { red blood cell (RBC) folate, } \\
\text { serum folate and serum } \\
\text { Vitamin } B_{12}\end{array}$ & $\begin{array}{l}\text { Pearson correlation coefficient between folate intake and serum } \\
\text { folate was } 0.65 \text { ( } p<0.01) \text {, excluding supplement users, which } \\
\text { decreased the association to } 0.46 \text { ( } p<0.01) \text {. Correlation between } \\
\text { folate intake and RBC folate concentration was } 0.50(p<0.01) \text {, } \\
\text { excluding supplement users, and adjusting for subject variation in } \\
\text { folate intakes the association was significant ( } r=0.23, p=0.01) \text {. } \\
\text { Correlation between Vitamin } B_{12} \text { intake and serum Vitamin } B_{12} \text { was } \\
0.32 \text { ( } p<0.01) \text {, with no difference in associations when adjusting } \\
\text { for energy and/or age. }\end{array}$ \\
\hline $\begin{array}{l}\text { Goodwin et al }{ }^{22} \\
2001\end{array}$ & $\begin{array}{l}\text { Food and activity record } \\
\text { (FAR), portion-size model } \\
\text { booklet (PSB) }\end{array}$ & $\begin{array}{l}\text { Adolescents } \\
(\mathrm{n}=54) \\
10-17 \mathrm{yr}\end{array}$ & $\begin{array}{l}\text { Relative validity, with } \\
\text { a standardised meal } \\
\text { including solids and liquids }\end{array}$ & $\begin{array}{l}\text { Adolescents 10-12 yr used the FAR and PSB with little or no } \\
\text { parental help. } \\
\text { Adolescents } 13-17 \text { yr could use the FAR and PSB independently. }\end{array}$ \\
\hline $\begin{array}{l}\text { Bandini et al }{ }^{38} \\
2003\end{array}$ & $\begin{array}{l}\text { Weighed food record } \\
\text { ( } 2 \text { weeks) }\end{array}$ & $\begin{array}{l}\text { Girls } \\
(\mathrm{n}=26) \\
10,12 \text { and } 15 \mathrm{yr}\end{array}$ & $\begin{array}{l}\text { Absolute validity, TEE by } \\
\text { DLW }\end{array}$ & $\begin{array}{l}\text { The accuracy of energy intake reporting was as follows: } \\
\text { at } 10 \text { years } 88 \pm 13 \% \\
\text { at } 12 \text { years } 77 \pm 21 \% \\
\text { at } 15 \text { years } 68 \pm 17 \% \text {. } \\
\text { The decline in accurate energy intake reporting from those of ages } \\
10-12 \text { yr and from } 10-15 \text { yr was statistically significant }(p=0.03 \\
\text { and } 0.001 \text {, respectively). }\end{array}$ \\
\hline
\end{tabular}

intakes, especially in girls, could be due to preoccupation with body weight, body frame and body image. A few studies showed an underestimation of total energy intake in 15-18 year olds, and which was especially apparent in obese girls. ${ }^{14,38,41,44}$

\section{Food frequency questionnaires (FFQs)}

Considering the strengths of the FFQ it seems ideal for use in epidemiological studies (see Table I). From a research point of view, one advantage of a FFQ is that individuals can be ranked according to their intake of specific foods and/or nutrients into quantiles (such as thirds or quarters of the distribution of intakes) in order to determine the relative risk of disease for different quantiles. Molag et al suggested that the inclusion of more than 200 food items in a FFQ improves the ranking of participants for most nutrients compared to a shorter FFQ. ${ }^{49}$
FFQs have some limitations as highlighted in Table I. Arguably, one of the most serious limitations is the reliance on the participants' abilities to recall the frequencies of intakes over past weeks, months or years. ${ }^{5}$ Another concern, particularly in culturally diverse populations, such as those of South Africa, is that the food items in the FFQ must be appropriate for the food habits of, and understood by, the study populations. ${ }^{5,50}$ Regarding the ability of adolescents to accurately respond to FFQs, adolescents younger than 13 years appear to need assistance from parents, ${ }^{21}$ while older adolescents tend to guess portion sizes rather than to refer to available portion size measurement aids..$^{22,23}$

As an example of the use of FFQs in an epidemiological study the reader is referred to one of the largest longitudinal studies in South Africa, the Birth-to-Ten Study, and subsequently the Birth-to-Twenty Study. A semi-quantitative food frequency questionnaire (SQFFQ) 
was used in these studies to determine and trace children's/ adolescents' diets as a whole at different age intervals. ${ }^{50-51}$ In the Birth-to-Ten Study, ${ }^{50} 163$ black children were seen at four interventions (1995-2000) when they were 5, 7, 9 and 10 years old In the Birth-to-Twenty Study, ${ }^{51} 143$ black adolescents were seen at two intervals (2000 and 2003) at 10 and 13 years old, respectively. Using the dietary data obtained in these studies the researchers were able to compare the children's/adolescents' energy and nutrient intakes with the recommended dietary allowances (RDAs), and to track changes over time. The same SQFFQ was used at all interventions, which ensured consistency in dietary assessment. However, this might have resulted in exclusion of some core foods as food choices changed over time in the cohort. The researchers acknowledged this limitation and emphasised that the dietary data are only estimates of actual intakes. Nevertheless, in large-scale epidemiological studies where the long-term diet is the important issue, using a FFQ is easier and more cost-effective than other dietary assessment methods. ${ }^{52}$

\section{Validity and reproducibility of FFQs}

Several studies have tested the relative validity of specific FFQs as a dietary assessment tool in adolescents (see Table III). ${ }^{53-57}$ In order to provide sufficient precision for FFQ validation the sample size of these studies should be at least 100 , and between 150 and 200 when the age range is larger and number of replicates per participant is limited. ${ }^{58}$ Only two of the validation studies summarised in Table IV had a sample size of $\geq 150$, and which should be considered when interpreting the results. Another important component of the validation process is choosing the appropriate reference method. The errors of the reference method should be as independent as possible from those of the test method. Therefore, in the case of FFQs a reference method that does not rely on memory and perception of portion sizes is probably the better choice. Food records are most likely to have the least correlated errors with FFQs since they are independent of memory and portion sizes are weighed or estimated at the time of consumption. ${ }^{59}$ Repeated (multiple) 24-hour recalls are an alternative to food records if participant burden or the likelihood of participants changing their diets seems to be a potential problem. However, errors are more likely to be correlated with those of FFQs due to reliance on memory, conceptualisation of portion sizes, and distortion of reported diet. ${ }^{58}$

From Table III it can be concluded that quantitative and semiquantitative FFQs appear to give a valid reflection of certain nutrient and food group intakes of adolescents. It is however important to realise that the relative validity of nutrients derived from a given FFQ is frequently not consistent. ${ }^{58}$ In general, FFQs' intakes of vitamin A, iron, protein and polyunsaturated fatty acid often show weak correlation coefficients with intakes derived from reference methods. Reasons for this could be that the food lists did not adequately reflect intakes of these nutrients ${ }^{58,60,61} \mathrm{and} /$ or the frequency of consumption options was not specific enough to reflect intakes. Another possible reason for poor correlations between intakes of nutrients such as Vitamin A, iron and polyunsaturated fatty acids derived from FFQs and those derived from reference methods is the large day-to-day variation in intakes of these nutrients among adolescents. ${ }^{57}$ Thus, if one wants to assess specific nutrients, the FFQ should be designed to include food sources high in these and to provide sufficient options of frequency of consumption to reflect day-to-day variations in intake.
Matthys et al developed a novel web-based self-administered semiquantitative FFQ (SQFFQ), which has the advantages of being costeffective and having a substantially lower respondent burden, and it eliminates possible researcher coding and entry errors. ${ }^{54}$ Despite these advantages the range of Spearman correlation coefficients was similar to that of other FFQ studies (see Table III). Further modification of this questionnaire could however result in an exciting new possibility of administering future SQFFQs among adolescents.

Reproducibility of FFQs can be influenced by the time period between repeated measurements. In adolescents too long a period $(\geq 12$ months) may result in changes in dietary habits, while too a short period may influence the responses of participants due to memory of questions and repeating answers. Frank et al reported that, when the interval between two repeated FFQ (completed by 1108 adolescents, 12-17 years old) was extended from several days to several weeks, the mean correlation coefficient decreased from 0.96 to 0.50 $(p \leq 0.05) .^{62}$ Decreased reproducibility that may occur after adjustments for energy intake can be due to systematic errors of overestimation and underestimation between repeated FFQs. Increased correlation coefficients on the other hand are often found when the variability in nutrient intake is related to energy intake. ${ }^{57}$

Considering the results of the studies summarised in Table III, 15,43,53$55,57,63-65 \mathrm{FFQs}$ seem to have a good reproducibility among adolescents and that gender, but not age, has an effect thereon. Although the age range of the study of Macintyre et al was from 15 to 65 years (11\% younger than 25 years), it is included in Table III as it is the only published South African study reporting the reproducibility of a FFQ. ${ }^{14}$ Macintyre et al ${ }^{14}$ found poor to moderate reproducibility in a culturesensitive quantitative FFQ (QFFQ) tested on Tswana-speaking South Africans from the North-West Province. These authors suggest that causes for poor reproducibility could include the use of different fieldworkers during the interviews and irregular consumption of certain foods such as samp and legumes.

\section{Twenty-four-hour recall method}

The 24-hour recall method was developed by Wiehl66 in 1942, and is still used today. The advantage of the 24-hour recall is that it is applicable for populations of different ethnicities (see Table I). ${ }^{20}$ It is a rapid, non-invasive dietary tool, and one with the ability to quantify daily intakes for populations in developing countries. ${ }^{4,9}$ The questionnaire is administered by a trained interviewer who should be knowledgeable on the terminology and locally available, traditional foods and beverages. ${ }^{5,32}$ Disadvantages of this method are that the respondents' recall depends on memory, portion sizes are difficult to estimate, and trained interviewers are required..$^{20}$ However, considering the advantages of the 24-hour recall method and its simplicity, it is thought to be the most useful method when gathering dietary data from adolescents. ${ }^{22}$

\section{Validity and reproducibility of 24-hour recalls}

When reviewing research from 1979 to 2000 , Gibson suggested that a reproducible estimation of the mean usual nutritional intake of a group may be found when a calculated number of 24-hour recall assessments (required to convey the average intakes of micronutrients) are done on non-consecutive days. ${ }^{4,9}$ More 24-hour recalls are needed to calculate the usual nutritional intake of an individual. ${ }^{4}$ In addition, all days of the week should be represented 
Table III: Validity and reproducibility of food frequency questionnaires (FFQs)

\begin{tabular}{|c|c|c|c|c|c|}
\hline Author & $\begin{array}{l}\text { Dietary } \\
\text { assessment } \\
\text { method }\end{array}$ & Sample size & $\begin{array}{l}\text { Reproducibility } \\
\text { tested? }\end{array}$ & $\begin{array}{l}\text { Validated? } \\
\text { Reference method }\end{array}$ & Results \\
\hline $\begin{array}{l}\text { Rocket et al }{ }^{63} \\
1995\end{array}$ & $\begin{array}{l}\text { Self-administered } \\
\text { SQFFQ } 1 \text { at } \\
\text { baseline and } \\
\text { SQFFQ2 at } 50 \\
\text { weeks }\end{array}$ & 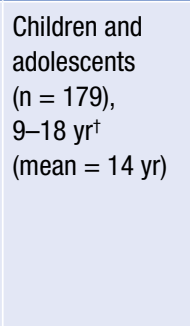 & $\begin{array}{l}\text { Yes; by assessing } \\
1 \text {-yr test-retest } \\
\text { reproducibility using } \\
\text { energy, protein, } \\
\text { carbohydrate, fat, } \\
\text { fiber, calcium and } \\
\text { iron }\end{array}$ & No & $\begin{array}{l}\text { El was significantly lower for FFQ2. } \\
\text { Energy-adjusted Pearson correlation coefficients for nutrient } \\
\text { intake ranged from } 0.26 \text { for protein to } 0.58 \text { for calcium. } \\
\text { Gender was related to reproducibility ( } r=0.17, p=0.025) \text {, but } \\
\text { not age }(r=0.07, p=0.35 \text { ) or ethnicity ( } r=0.045, p=0.55) \text {. } \\
\text { Pearson correlation coefficients for servings per day of food } \\
\text { groups ranged from } 0.39 \text { for meats to } 0.57 \text { for soda. } \\
\text { Correlation coefficients were higher for girls than boys, except for } \\
\text { the intake of soda. }\end{array}$ \\
\hline $\begin{array}{l}\text { Green et al }{ }^{43} \\
1998\end{array}$ & $\begin{array}{l}\text { SQFFQ and 3-day } \\
\text { WFRs }^{\ddagger}\end{array}$ & $\begin{array}{l}\text { Adolescent girls } \\
(\mathrm{n}=105), \\
16-19 \mathrm{yr}, \\
\text { supplement vs. } \\
\text { non-supplement } \\
\text { users }\end{array}$ & No & $\begin{array}{l}\text { Absolute validity, } \\
\text { by correlating red } \\
\text { blood cell (RBC) } \\
\text { folate, serum folate } \\
\text { and serum vitamin } \\
\mathrm{B}_{12} \text { with the SQFFQ } \\
\text { and 3-day WFR }\end{array}$ & $\begin{array}{l}\text { Pearson correlations between folate intake of all subjects and } \\
\text { RBC folate concentrations were } r=0.42(p<0.01) \text {. } \\
\text { Excluding supplement users, the association between folate } \\
\text { intake and RBC folate concentration remained significant ( } r= \\
0.25, p=0.03) \text {. } \\
\text { Pearson correlations between Vitamin } B_{12} \text { intake of all subjects } \\
\text { and serum Vitamin } B_{12} \text { concentrations were } r=0.25(p=0.01) \text {. } \\
\text { Excluding supplement users, resulted in a non-significant } \\
\text { association between Vitamin } B_{12} \text { intake and serum Vitamin } B_{12} \\
\text { concentrations }(r=0.19, p=0.09) \text {. }\end{array}$ \\
\hline $\begin{array}{l}\text { Maclntyre et al } \\
2001\end{array}$ & $\begin{array}{l}\text { QFFQ1 administered } \\
\text { at baseline and } \\
\text { QFFQ2 } 6 \text { to } 12 \\
\text { weeks after first } \\
\text { interview (mean } \\
\text { time between two } \\
\text { QFFQs was } 58 \pm 27 \\
\text { days) }\end{array}$ & $\begin{array}{l}\text { Adolescents and } \\
\text { adults } \\
(\mathrm{n}=144) \text {, } \\
15-65 \text { yr. } \\
50 \% \text { of sample } \\
\text { between } 15 \text { and } \\
34.6 \mathrm{yr}\end{array}$ & $\begin{array}{l}\text { Yes; mean reported } \\
\text { intakes from QFFQ1 } \\
\text { and QFFQ2 for } \\
\text { energy, protein, } \\
\text { carbohydrate, fat, } \\
\text { fibre, calcium, } \\
\text { iron, Vit. A, Vit. C } \\
\text { and alcohol were } \\
\text { compared for the } \\
\text { entire sample, } \\
\text { gender, urbanisation } \\
\text { and age groups }\end{array}$ & No & $\begin{array}{l}\text { Spearman rank correlation coefficients between QFFQ1 and } \\
\text { QFFQ2 ranged from } 0.14 \text { for calcium (non-significant) to } 0.75 \text { for } \\
\text { alcohol. } \\
\text { No significant differences in correlation coefficients among age } \\
\text { groups for any nutrients tested ( } p>0.05 \text { ) were found. } \\
\text { For food groups, correlation coefficients ranged from } 0.25 \text { for } \\
\text { milk and } 0.45 \text { for vegetable and maize meal groups. }\end{array}$ \\
\hline $\begin{array}{l}\text { Macintyre et al } \\
2001\end{array}$ & $\begin{array}{l}\text { QFFQ and 7-day } \\
\text { WFRs }\end{array}$ & $\begin{array}{l}\text { Adolescents and } \\
\text { adults } \\
(\mathrm{n}=74) \text {, } \\
59 \text { females and } \\
15 \text { males, } \\
15-65 \mathrm{yr}\end{array}$ & No & $\begin{array}{l}\text { Relative validity } \\
7 \text {-day WFRs and } \\
\text { absolute validity } \\
\text { with urinary nitrogen }\end{array}$ & $\begin{array}{l}\text { Relative validity: Spearman rank correlation coefficient for } \\
\text { untransformed nutrient intake between the QFFQ and mean } \\
\text { WFRs ranged between } 0.20 \text { for iron and } 0.59 \text { for Vitamin C. } \\
\text { The QFFQ tended to underestimate intakes compared with the } \\
\text { WFRs. Correlation between urinary nitrogen excretion and dietary } \\
\text { intake was poor. Possible underreporting was identified for } 43 \% \\
\text { of participants with QFFQ and } 28 \% \text { with WFRs. }\end{array}$ \\
\hline $\begin{array}{l}\text { Deschamps } \\
\text { et al }{ }^{53} \\
2009\end{array}$ & $\begin{array}{l}\text { FFQ administered at } \\
\text { baseline and after } \\
12 \text { months }\end{array}$ & $\begin{array}{l}\begin{array}{l}\text { Adolescents } \\
(\mathrm{n}=37) \\
10-18 \mathrm{yr}\end{array}\end{array}$ & $\begin{array}{l}\text { Yes; means and } \\
\mathrm{SD}^{\otimes} \text { for food } \\
\text { consumption and } \\
\text { nutrient intake were } \\
\text { calculated for both } \\
\text { FFQs }\end{array}$ & $\begin{array}{l}\text { Relative validity } \\
4 \times 24-h \S \text {; means } \\
\text { and SDs for nutrient } \\
\text { and food intakes } \\
\text { were determined for } \\
\text { both FFQs and the } \\
\text { average of the } 4 x \\
\text { 24-h. Within-person } \\
\text { and between-person } \\
\text { variances were } \\
\text { compared. }\end{array}$ & $\begin{array}{l}\text { Relative validity: No differences in energy and nutrients } \\
\text { measured by FFQ1 and FFQ2. } \\
\text { De-attenuated Pearson correlation coefficients between FFQ2 } \\
\text { and } 24-\mathrm{h} \text { ranged between } 0.45 \text { and } 0.70 \text { for most nutrients. } \\
\text { Pearson correlation coefficients for food items were similar } \\
\text { between FFQs and } 24-h \text {. De-attenuated Pearson correlation } \\
\text { coefficients between FFQ2 and } 24-\mathrm{h} \text { ranged from } 0.02 \text { for eggs } \\
\text { to } 0.76 \text { for milk. } \\
\text { Reproducibility: Intraclass correlation coefficients for two FFQs } \\
\text { ranged from } 0.40 \text { to } 0.60 \text { for most nutrients and to } 0.83 \text { for } \\
\text { alcohol. Intraclass correlation coefficients for two FFQs ranged } \\
\text { from } 0.35 \text { to } 0.60 \text { for most food items; lower coefficients }(0.11) \\
\text { were for rarely eaten foods such as inner organs. }\end{array}$ \\
\hline $\begin{array}{l}\text { Matthys et a }\left.\right|^{54} \\
2007\end{array}$ & $\begin{array}{l}\text { Self-administered, } \\
\text { web-based SQFFQ, } \\
\text { completed twice } \\
\text { (baseline and } 1 \\
\text { month after EFR) } \\
\text { and 3-day EFR } \\
\text { (2 weekdays and } 1 \\
\text { weekend day) }\end{array}$ & $\begin{array}{l}\text { Adolescents } \\
(\mathrm{n}=104) \\
12-18 \mathrm{yr}\end{array}$ & $\begin{array}{l}\text { Yes; Spearman } \\
\text { correlation } \\
\text { coefficient for all } \\
69 \text { food items } \\
\text { were assessed for } \\
\text { a subgroup of } 66 \\
\text { subjects }\end{array}$ & $\begin{array}{l}\text { Relative validity, } \\
\text { using EFRs }{ }^{* *} \text { and } \\
\text { FFQs }\end{array}$ & $\begin{array}{l}\text { Relative validity: The average Spearman correlation coefficient of } \\
\text { food groups between EFRs and SQFFQ was } 0.38 \text { (ranging from } \\
0.20 \text { for pasta/rice to } 0.64 \text { for breakfast cereals). } \\
\text { Only } 6 \text { of } 15 \text { food groups had a correlation }>0.4 \text {; for all foods } \\
\text { collectively the correlation was } 0.30 \text {. } \\
\text { Reproducibility: Spearman correlation coefficients ranged from } \\
0.27 \text { for fish/eggs/meat to } 0.87 \text { for alcoholic beverages; the } \\
\text { average correlation coefficient for all foods collectively was } 0.62 \text {. } \\
\text { According to the results, it was concluded that the Web-based } \\
\text { FQQ is not able to adequately determine absolute food intakes. }\end{array}$ \\
\hline
\end{tabular}


Table III: Validity and reproducibility of food frequency questionnaires (FFQs)

\begin{tabular}{|c|c|c|c|c|c|}
\hline Author & $\begin{array}{l}\text { Dietary } \\
\text { assessment } \\
\text { method }\end{array}$ & Sample size & $\begin{array}{l}\text { Reproducibility } \\
\text { tested? }\end{array}$ & $\begin{array}{l}\text { Validated? } \\
\text { Reference method }\end{array}$ & Results \\
\hline $\begin{array}{l}\text { Watson et al }{ }^{57} \\
2009\end{array}$ & $\begin{array}{l}\text { SQFFQ at baseline } \\
\text { (FFQ1) and after } 5 \\
\text { months (FFQ2); and } \\
4 \times 1 \text {-day assisted } \\
\text { EFRs }\end{array}$ & $\begin{array}{l}\text { Boys } \\
(\mathrm{n}=40) \\
\text { and girls } \\
(\mathrm{n}=73) \\
9-16 \mathrm{yr}\end{array}$ & $\begin{array}{l}\text { Yes; comparing } \\
\text { FFQ1 and FFQ2 } \\
\text { ( } \mathrm{n}=101) \text { using } \\
\text { correlations, Kappa } \\
\text { statistics and Bland- } \\
\text { Altman plots }\end{array}$ & $\begin{array}{l}\text { Relative validity, } \\
\text { comparing the } \\
\text { average of the } 4 x \\
\text { assisted EFRs with } \\
\text { FFQ2 } \\
(\mathrm{n}=113) \\
\text { as well as the } \\
\text { average of FFQ1 } \\
\text { and FFQ2 } \\
(\mathrm{n}=101)\end{array}$ & $\begin{array}{l}\text { Relative validity: No differences in energy and nutrients } \\
\text { measured by FFQ1 and FFQ2. Unadjusted Spearman correlation } \\
\text { coefficients between FFQ2 and EFRs ranged from } 0.09 \text { for } \\
\text { retinol to } 0.35 \text { for calcium, with a median of } 0.25 \text {. Adjusted (de- } \\
\text { attenuated, energy-adjusted, transformed) correlations ranged } \\
\text { from } 0.17 \text { for niacin equivalents to } 0.56 \text { for magnesium, with a } \\
\text { mean of } 0.39 \text {. } \\
\text { Reproducibility: Median correlation coefficient for unadjusted } \\
\text { nutrient intakes of the two FFQs was } 0.46 \text {. } \\
\text { Adjusted (transformed, energy-adjusted) mean correlation } \\
\text { coefficient for nutrient intakes was } 0.32 \text {. }\end{array}$ \\
\hline $\begin{array}{l}\text { Hong et al }{ }^{55} \\
2009\end{array}$ & $\begin{array}{l}\text { FFQ1 at baseline, } \\
\text { FFQ2 at } 4 \text { weeks } \\
\text { from baseline and } \\
\text { FFQ3 at } 6 \text { months } \\
\text { from baseline; } \\
\text { and } 4 \text { x } 24 \text {-h over } \\
\text { the same period } \\
\text { (collected with } \\
5 \text {-week intervals). }\end{array}$ & $\begin{array}{l}\text { Adolescents } \\
(\mathrm{n}=177) \\
11-14 \mathrm{yr}\end{array}$ & $\begin{array}{l}\text { Yes, using weighed } \\
\text { Kappa values }\end{array}$ & $\begin{array}{l}\text { Relative validity } 4 \\
\text { x 24-h; comparing } \\
\text { mean nutrient intake } \\
\text { data obtained from } \\
\text { FFQ1 and FFQ3 with } \\
\text { mean nutrient intake } \\
\text { data obtained from } \\
\text { four } 24-h\end{array}$ & $\begin{array}{l}\text { Relative validity: Unadjusted Pearson correlation coefficients } \\
\text { between average FFQ and average } 24 \text {-h ranged from } 0.32 \text { for } \\
\text { stearic acid to } 0.64 \text { for fibre, with a mean of } 0.42 \text {. } \\
\text { De-attenuated Pearson correlation coefficients ranged from } \\
0.39 \text { for stearic acid to } 0.68 \text { for fiber, with a mean of } 0.41 \text { for } \\
\text { micronutrients and } 0.49 \text { for macronutrients. } \\
\text { Reproducibility: Adjusted (energy-adjusted) Pearson correlation } \\
\text { coefficients between FFQ1 and FFQ2 ranged from } 0.22 \text { for retinol } \\
\text { to } 0.78 \text { for fiber (short-term reproducibility). } \\
\text { Adjusted correlation coefficients (energy-adjusted) between FFQ1 } \\
\text { and FFQ3 ranged from } 0.3 \text { for retinol to } 0.81 \text { for zinc (long-term } \\
\text { reprod.). } \\
\text { Coefficients for nutrients between the mean of the three } \\
\text { FFQs and the mean of four } 24 \text {-h were } \pm 0.40 \text {, but higher for } \\
\text { energy-adjusted nutrients ( } 0.52 \text { for macronutrients and } 0.46 \text { for } \\
\text { micronutrients). }\end{array}$ \\
\hline $\begin{array}{l}\text { Taylor et al }{ }^{56} \\
2009\end{array}$ & $\begin{array}{l}\text { FFQ assessing } \\
\text { calcium and Vitamin } \\
D \text { intake and a } \\
\text { 4- day EFRs ( } 3 \\
\text { weekdays and } 1 \\
\text { weekend day) }\end{array}$ & $\begin{array}{l}\text { Adolescent girls } \\
\text { with anorexia } \\
\text { nervosa } \\
(A N, n=36) \text { and } \\
\text { healthy controls } \\
(n=39) \text {, } \\
12-18 \mathrm{yr}\end{array}$ & No & One 4-day EFRs & $\begin{array}{l}\text { Adjusted calcium (for energy-intake) FFQ was greater than } \\
\text { adjusted calcium EFR ( } 623 \pm 52 \text { vs. } 501 \pm 24 \text { mg, } p=0.04) \\
\text { in controls. Adjusted Vitamin D FFQ was lower than adjusted } \\
\text { Vitamin D EFR ( } 117 \pm 13 \text { vs. } 153 \pm 14 \mathrm{IU}, \mathrm{p}=0.04) \text { in AN. } \\
\text { In the total group the calcium EFR correlated positively with } \\
\text { calcium FFQ ( } r=0.60, p<0.0001) \text {, as well as Vit. D EFR with } \\
\text { Vit. D FFQ } \\
\text { ( } r=0.75, p<0.001) \text {. } \\
\text { Adjusted calcium EFR had a weaker correlation with adjusted } \\
\text { calcium FFQ ( } r=0.32, p=0.006) \text {, but stronger for adjusted } \\
\text { Vitamin D EFR with adjusted Vitamin D FFQ ( } r=0.62, p< \\
0.0001) \text {. }\end{array}$ \\
\hline $\begin{array}{l}\text { 'SQFFQ: semi-quant } \\
\text { 'yr: years } \\
\text { †WFRs: weighed foo } \\
\text { \$24-h: 24-hour } \\
\text { 口SD: standard devia } \\
\text { "EFRs: estimated fo }\end{array}$ & $\begin{array}{l}\text { tive food frequency questionn } \\
\text { records }\end{array}$ & haire & & & \\
\hline
\end{tabular}

when one wants to refer to the average nutrient intake of a group. Repeated 24-hour recalls per participant are needed to be able to indicate if an individual, group or populations is at risk for specific nutrient deficiencies. These recalls should be taken on at least two non-consecutive days, and if this is not possible, recalls of at least three consecutive days should be taken. However, because of the respondent burden and cost, a maximum of four 24-hour recalls per person is usually feasible, regardless of the extent of the withinsubject variation. ${ }^{4,9}$

As indicated in Table IV, very few reproducibility and validity studies have been conducted on the 24-hour dietary recall method among adolescents. Since adolescents' eating habits and patterns are sometimes erratic and change continuously, repeated 24-hour recalls will be needed in order to obtain a better representative sample of their usual dietary intake. When dealing with adolescents one must keep in mind that they have social, emotional and physical issues that influence their food intake, and which may lead to inaccurate data. ${ }^{33}$ Dietary data should always be interpreted with caution since accuracy of multiple 24-hour recalls is influenced by BMI (the lower the BMI, the lower the omission and intrusion rate). ${ }^{67}$

The 24-hour recall method could lead to significant problems of precision within the same individual, but internal and external validity has been found to be at an acceptable level in adolescents aged ten years and older. ${ }^{20}$ When evaluating the validity of a 24-hour recall questionnaire against a WFR and observed reports, respectively, under-reporting of $22.1 \%^{68}$ and $25 \%{ }^{69}$ for energy was found. The difficulty that children have in correct estimation of portion sizes, ${ }^{68-69}$ which is the most challenging part of the 
Table IV: Validity and reproducibility of the 24-hour recall method

\begin{tabular}{|c|c|c|c|c|c|}
\hline Author & $\begin{array}{l}\text { Dietary assessment } \\
\text { method }\end{array}$ & Sample size & Reproducibility & $\begin{array}{l}\text { Validated? } \\
\text { Reference method }\end{array}$ & Results \\
\hline $\begin{array}{l}\text { Koehler et al }{ }^{71} \\
2000\end{array}$ & $\begin{array}{l}\text { Yesterday's food choice } \\
\text { (YFC) - questions were read } \\
\text { out aloud while students } \\
\text { followed along and marked } \\
\text { their answers; and } 24-h^{\star} \\
\text { recall (administered after } \\
\text { the YFC and in the same } \\
\text { morning, before lunch). }\end{array}$ & $\begin{array}{l}\text { Adolescents } \\
(n=120), \\
10-14 \mathrm{yr}\end{array}$ & No. & $\begin{array}{l}\text { Relative validity, } \\
\text { YFC with reference } \\
\text { method (24-h } \\
\text { recall). } \\
\text { The validation } \\
\text { sample was small } \\
\text { and not selected } \\
\text { randomly. }\end{array}$ & $\begin{array}{l}\text { YFC showed poor agreement for most items on the } 24-\mathrm{h} \text { recall. } \\
\text { Only } 5 \text { out of } 30 \text { items showed agreement ( } 0.4 \text { and } 0.59 \text { for } \\
\text { eggs and deep fried foods, respectively; and cereal, low-fat and } \\
\text { mutton with values } \geq 0.60 \text { ), meaning low validity Kappa of } \\
0.68 \text { for consumption of milk shows a } 68 \% \text { of possible } \\
\text { agreement between the two methods. } \\
\text { Further development on the YFC is needed. The YFC cannot be } \\
\text { used with success in adolescents. }\end{array}$ \\
\hline $\begin{array}{l}\text { Smith et al }{ }^{72} \\
2001\end{array}$ & $\begin{array}{l}\text { 24-h recall ( } 3 \text { days) and } \\
\text { CFC }{ }^{\dagger} \text {. } \\
\text { Subjects randomly assigned } \\
\text { to } A, B \text { and } C \text { groups. } \\
\text { Groups } A \text { and } B \text { ( } n=243 \text { ) } \\
\text { completed both the CFC and } \\
\text { a } 24-h \text { recall at different } \\
\text { times on the same day } \\
\text { (morning before lunch and } \\
\text { late afternoon), which took } \\
35-40 \text { min). } \\
\text { Group } C \text { ( } n=122) \text { completed } \\
\text { only the CFC on the same } \\
\text { day ( } 2 \text { hours apart). }\end{array}$ & $\begin{array}{l}\text { Male and } \\
\text { female } \\
\text { adolescents } \\
(\mathrm{n}=365) \\
7^{\text {th }} \text { grade } \\
\text { (168 males } \\
\text { and197 } \\
\text { females ), } \\
\text { multi-ethnic } \\
\text { sample }\end{array}$ & $\begin{array}{l}\text { Yes. } \\
\text { Child and } \\
\text { adolescent } \\
\text { trial for } \\
\text { cardiovascular } \\
\text { health (CATCH) } \\
\text { food checklist } \\
\text { (FC) (CFC) }\end{array}$ & $\begin{array}{l}\text { Relative validity, } \\
\text { independent coding } \\
\text { of } 30 \text { CFCs by two } \\
\text { persons. }\end{array}$ & $\begin{array}{l}\text { Reliability (reproducibility) }{ }^{10} \text { was measured by the concordance } \\
\text { between morning and afternoon administrations of the CFC. To } \\
\text { assist inter-rater consistency, researchers rated } 30 \text { randomly } \\
\text { selected CFCs that had been assigned to other members. Kappa } \\
\text { values, measuring correspondence between morning and } \\
\text { afternoon reports had a median value of } 0.85 \text {. Kappa values of } \\
\geq 0.61 \text { indicated substantial reliability agreement. } \\
\text { Validity was evaluated by independent coding of a CFC based } \\
\text { on foods reported on the } 24 \text {-h recall. Test-retest reliability } \\
\text { coefficients ranged from } 0.84 \text { to } 0.89 \text { for CFC total nutrient } \\
\text { scores. In validation of } 10 \text { food-choice pairs, the highest Kappa } \\
\text { value was } 0.22 \text {. Correlations between CFC and } 24-h \text { values } \\
\text { were } 0.36 \text { for total fat and saturated fat, and } 0.34 \text { for sodium. } \\
\text { Researchers found that } 24-h \text { recall is more precise than CFC. }\end{array}$ \\
\hline $\begin{array}{l}\text { Kruger et al }{ }^{37} \\
2006\end{array}$ & $\begin{array}{l}\text { 24-h recall (duplicate on } \\
\text { sub sample). The time of the } \\
\text { duplicate } 24-\mathrm{h} \text { recall was not } \\
\text { indicated. }\end{array}$ & $\begin{array}{l}\text { Adolescents } \\
(n=1257), \\
10-15 \mathrm{yr}\end{array}$ & $\begin{array}{l}\text { Yes. } \\
\text { Tested with a } \\
\text { duplicate } 24-\mathrm{h} \\
\text { recall on a sub- } \\
\text { sample of } 289 \\
\text { children. }\end{array}$ & $\begin{array}{l}\text { Relative validity, } \\
\text { 3-day estimated } \\
\text { weighed food } \\
\text { record in sub- } \\
\text { sample of } 40 \\
\text { children selected } \\
\text { through convenient } \\
\text { sampling. }\end{array}$ & $\begin{array}{l}\text { Spearman correlation coefficients were used to assess the } \\
\text { reproducibility of the dietary intakes measured by the initial } \\
\text { and duplicate } 24 \text {-hour recalls. Dietary intake data obtained by } \\
\text { 24-h recall were reproducible. Validity was tested by a 3-day } \\
\text { estimated weighed food record in a sub sample of } 40 \text { children. } \\
\text { Underreporting for fibre and } 5 \text { micronutrients, over-reporting for } \\
\text { two micronutrients were found. }\end{array}$ \\
\hline $\begin{array}{l}\text { Cullen et al }{ }^{73} \\
2008\end{array}$ & $\begin{array}{l}24 \mathrm{~h} \text { recall (duplicate): } \\
\text { duplicate } 24-\mathrm{h} \text { recall } \\
\text { completed within a } 7 \text { day } \\
\text { period and after that the } \\
\text { Block Kids Questionnaire } \\
\text { (BKQ): Children self-reported } \\
\text { their consumption of } 72 \\
\text { food/beverage items for } \\
\text { the past } 2 \text { days (1 weekday } \\
\text { and } 1 \text { weekend day) using } \\
6 \text { response categories (from } \\
\text { none to everyday). }\end{array}$ & $\begin{array}{l}\text { Adolescents } \\
(\mathrm{n}=83) \\
\text { ( } 31 \text { diabetic } \\
\text { and } 52 \\
\text { non-diabetic), } \\
10-17 \mathrm{yr}\end{array}$ & $\begin{array}{l}\text { Yes } \\
\text { Test-retest } \\
\text { reliability. }\end{array}$ & $\begin{array}{l}\text { Relative validity, } \\
\text { BKQ. }\end{array}$ & $\begin{array}{l}\text { The adjusted and deattenuated correlation coefficients for } \\
\text { nutrients were between } 0.47 \text { and } 0.69 \text { with } 60 \% \text { being }<0.30 \text {. } \\
\text { Age related differential results in the validity between the BKQ } \\
\text { and } 24 \text {-h recall were observed. Most } 24 \text {-h recall mean estimates } \\
\text { were significantly greater than the mean BKQ estimates. } \\
\text { Test-retest reliability was assessed using the interclass } \\
\text { correlation coefficient }(>0.30) \text {. Significant differences between } \\
\text { the } 2 \text { methods }(p<0.01) \text { were found }\end{array}$ \\
\hline $\begin{array}{l}\text { Nelson and } \\
\text { Lytle }^{64} \\
2009\end{array}$ & $\begin{array}{l}24-h \text { recall ( } 3 \text { days) within } \\
\text { a } 15 \text { day period for } 2 \\
\text { weekdays and } 1 \text { weekend } \\
\text { day. } \\
\text { The screener and the first } \\
\text { recall were collected, on } \\
\text { average, within } 10 \text { days of } \\
\text { each other. }\end{array}$ & $\begin{array}{l}\text { White } \\
\text { adolescents } \\
(n=92) \\
11-18 \mathrm{yr}\end{array}$ & $\begin{array}{l}\text { Yes, } \\
\text { but only for the } \\
22 \text {-item dietary } \\
\text { screener. } \\
\text { Sub-sample } \\
(\mathrm{n}=33 \text { ) } \\
\text { completed test- } \\
\text { retest reliability } \\
\text { of the screener } \\
\pm 2-21 \text { days } \\
\text { apart. }\end{array}$ & $\begin{array}{l}\text { Criterion validity: } \\
\text { Completed } 22 \text {-item } \\
\text { dietary screener } \\
\text { along with } 3 \times 24-h \\
\text { recalls }(n=59) .\end{array}$ & $\begin{array}{l}\text { 24-h recalls done on } 2 \text { weekdays and } 1 \text { weekend day within a } \\
15 \text { day time period. } \\
\text { Reliability: Test-retests assessments were compared } 7-14 \text { days } \\
\text { apart, with substantial agreement between two administrations } \\
\text { yielding Spearman correlations and }{ }_{k} \text { statistics that were > } \\
0.60 \text {. Magnitude of agreement between the screener and } 24-h \\
\text { recalls is moderately lower than that reported in other dietary } \\
\text { questionnaire validity studies (Kappas ranging from } 0.19-0.38 \text {, } \\
\text { but statistically significant } \mathrm{p}<0.002 \text { ). } \\
\text { Criterion validity was tested against the Nutrition Data } \\
\text { System for Research data as gold standard and found to have } \\
\text { "acceptable", though modest, validity. Comparing the } 24-h \\
\text { recalls with the screener was challenging due to the response } \\
\text { periods captured by each instrument (recalls assessed intake } \\
\text { over } 3 \text { days, whereas the screener assessed intake over the } \\
\text { past month). }\end{array}$ \\
\hline
\end{tabular}


recall, ${ }^{4}$ may be resolved in adolescent years when a higher literacy level and brain development is reached. ${ }^{68}$ Graduated photographs showing food items, actual foods or salted replicas, modelling clay, tape measures or graduated food models, ${ }^{4}$ could improve correct estimation of food portion sizes. ${ }^{4,23}$ Another technique to increase reproducibility of the 24-hour recall is referred to as the multiple pass 24-hour recall. This technique increases retrieval of the requested information by allowing the participant to review the food and beverage intake of the previous 24 hours several times. The interviewer first investigates which foods the participant ate during the preceding 24-hour period, and then collects more detail about the foods consumed, the preparation methods, and finally the portion sizes. The multiple-pass, 24-hour recall method was developed to minimise under-reporting of dietary intake by providing respondents with multiple cues and opportunities to recall food intake..$^{9,70}$

\section{Discussion and conclusions}

Developing efficient, cost effective and valid tools for assessing the dietary intakes of adolescents are key research priorities. Although comprehensive FFQs have been developed to assess the diets of adolescents worldwide, only a limited number of validation studies have been undertaken. ${ }^{57}$ Population-based studies to test reproducibility and validity of dietary assessment methods in adolescents are relatively scarce, especially in South Africa.

The National Children's Study carried out by Potischman et al was one of the most recent and largest studies done and, according to their results, the best dietary assessment tools to use in adolescents are a combination of the FFQ and multiple 24-hour recalls. ${ }^{33}$ This was also the finding of Subar et al; they considered using statistical modelling to combine data from FFQs with those of a limited number of 24-hour recalls, because the defining characteristic of a FFQ is precisely that which the 24-hour recalls lacks (the probability of consumption or frequency of consumption over a specified time period). ${ }^{74}$ On the other hand, FFQs do not provide adequately detailed information about amounts consumed, while 24-hour recall methodology attempts to correctly quantify portion sizes for each eating occasion. Their findings show strong and consistent relationships for the majority of foods and food groups examined between the reported frequency of consumption based on a FFQ and the probability of consumption on four 24 -hour recalls. ${ }^{74}$

The study undertaken by Maclntyre et al regarding South African black adults and adolescents also showed that dietary assessment with FFQs leads to under-reporting of energy intake. ${ }^{65}$ Under-reporting is of great concern in adolescents' dietary intake assessment, even with WFR, which is believed to be one of the most accurate dietary assessment methods. ${ }^{45}$ Weighing and recording all consumed food and drinks is a burden for adolescents, who constantly form new eating habits, often eat take-away foods, easily become irritated and bored with the WFR process, or simply forget to weigh and notate all the consumed foods. EFRs eliminate the burden of weighing of foods, but still show under- and over-reporting when compared with WFRs. ${ }^{14,15,38,41-44}$ Weighed food records are also more time consuming than other methods. ${ }^{56}$ Factors such as preoccupation with body weight, frame and image (especially in girls), ${ }^{14}$ and difficulty estimating portion sizes, play a role in under- and over-reporting. ${ }^{22,23}$
Studies conducted on the validity of 24-hour recalls showed that even young children could estimate their energy intake of the last 24 hours with a $77.9 \%$ accuracy, but they overestimated portion sizes due to low literacy levels. ${ }^{37,68}$ The higher literacy level of adolescents could improve accuracy. ${ }^{68}$ Although this is a relatively simple method to assess dietary intake, the validity of data is poor when only one 24-hour recall is done. At least two to four assessments are needed for data to be reliable and valid. This method can be made more reliable and accurate if aids such as photographs with the same appearance as actual food items are used for the estimation of portion sizes. $^{23}$

The authors conclude that when each of the dietary assessment tools were compared with the most appropriate reference method (DLW method) the WFRs, EFRs and FFQs could represent biased results due to the retrospective estimation of the dietary intake. It is therefore recommended that more studies be undertaken in which individual methods (such as 24 -hour recall method) or a combination of dietary assessment methods (such as 24-hour recalls and FFQs) are compared to the most reliable reference method (DLW method) in South African adolescents. Dietary intake determined with a method not tested for validity and reproducibility should be interpreted or extrapolated with caution, due to imperfections of dietary methods, regardless of how well they are designed. It may well be worthwhile to study the work of Subar et al ${ }^{74}$ in more detail and use the strengths of different dietary intake methods in a statistical model in order to obtain a clear and accurate picture of the individual and group dietary intakes. The researchers caution, however, that the use of the frequency data of Subar et $\mathrm{al}^{74}$ should be used to supplement, and not replace, recall data.

\section{References}

1. Jones LL, Griffiths PL, Norris SA, Pettifor JM, Cameron N. Is puberty starting earlier in urban South Africa? Am J Hum Boil. 2009, [Epub ahead of print].

2. Story $M$, Neumark-Sztainer $D$. Individual and environmental influences on adolescents eating behaviours. J Am Diet Assoc 2002;102(Suppl):S40-S51.

3. American Academy Of Pediatrics. Policy Statement: Promotion of healthy weight-control practices in young athletes. Paediatrics 2005;116:1557-64.

4. Gibson RS. Introduction. In: Gibson RS, eds. Principles of Nutritional Assessment. Oxford New York: Oxford University Press, 2005:1-26

5. Deakin V. Measuring nutritional status of athletes: clinical and research perspectives. In: Burke L, Deakin V, eds. Clinical sports nutrition. Australia: McGraw-Hill Australia Pty Ltd, 2006:21-51.

6. Sichert-Hellert W, Kersting M, Chahda C, Schäfer R, Kroke A. German food composition database for dietary evaluations in children and adolescents. J Food Comp Anal 2006;20:63-70.

7. Stanner S. Nutrition and teenagers. J Women's Health 2004;1:2-10.

8. Moreno LA, Kersting M, De Henauw S, et al. How to measure dietary intake and food habits in adolescence: the European perspective. Int J Obes 2005;29:566-77.

9. Gibson RS. Reproducibility in dietary assessment. In: Gibson RS, ed. Principles of nutritional assessment. New York: Oxford University Press; 2005:129-48.

10. Gibson RS. Validity in dietary assessment methods. In: Gibson RS, ed. Principles of Nutritional Assessment. New York: Oxford University Press; 2005:149-96.

11. Block G. A review of validation of dietary assessment methods. Am J Epid 1982;11:492-505.

12. Livingstone MBE, Prentice AM, Coward WA, et al. Validation of estimates of energy intake by weighed dietary record and diet history in children and adolescents. Am J Clin Nutr 1992;56:29-35.

13. Bandini LG, Cyr H, Must A, Dietz, WH. Validity of reported energy intake in preadolescent girls. Am J Clin Nutr 1997;65:S1138-41

14. Chinnock A. Validation of an estimated food record. Public Health Nutr 2006;9:934-41.

15. Macintyre UE, Venter CS, Vorster HH. A culture-sensitive quantitative food frequency questionnaire used in an African population: 1 Development and reproducibility. Public Health Nutr 2001;4:53-62.

16. Tarasuk V, Beaton GH. Statistical estimation of dietary parameters: implications of patterns in withinsubject variation--a case study of sampling strategies. Am J Clin Nutr 1992;55:22-7.

17. Lambe J, Kearney J, Leclercrq C, et al. Enhancing the capacity of food consumption surveys of short duration to estimate long-term consumer-only intakes by combination with a qualitative food frequency questionnaire. Food Addit Contam 2000;17:177-87 
18. Kersting M, Alexy U, Wolfgang SH. Dietary intake and food sources of minerals in 1 to 18 year old German children and adolescents. Nutr Res 2001;21:607-16.

19. Kroke A, Manz F, Kersting M, et al. The DONALD Study: history, current status and future perspective. Eur J Nutr 2004;43(1):45-54.

20. Biró G, Hulshof KF, Ovesen L, Amorim Cruz JA. Selection of methodology to assess food intake. Eur J Clin Nutr 2002;56:S25-32.

21. Haraldsdóttir J, Hermansen B. Repeated 24-h recalls with young schoolchildren. A feasible alternative to diet history from parents? Eur J Clin Nutr 1995;49:729-39.

22. Goodwin RA, Brule D, Junkins EA, Dubois S, Beer-Borst S. Development of a food and activity record and a portion-size model booklet for use by 6 -to 17 -year olds: A review of focus group testing. J Am Diet Assoc 2001;101:926-8.

23. Lillegaard ITL, Øverby NC, Andersen LF. Can children and adolescents use photographs of food to estimate portion sizes? Eur J Clin Nutr 2005;59:611-7.

24. Sempos, C.T. Some limitations of semiquantitative food frequency questionnaires [invited commentary] Am J Epidemiol 1992;135:1127-32.

25. Hartwell DL, Henry CJK. Comparison of a self-administered quantitative food amount frequency questionnaire with 4-day estimated food records. Int J Food Sci Nutr 2001;52:151-9.

26. Kim J, Chan MM, Shore RE. Development and validation of a food frequency questionnaire for Korean Americans. Int J Food Sci Nutr 2002;53:129-42.

27. Ishihare J, Inoue M, Kobayashi M, et al. Impact of the reversion of a nutrient database on the validity of a self-administered food frequency questionnaire. J Epidemiol 2006;16:107-16.

28. Labadarios D, Steyn N, Maubder E, et al. The National Food Consumption Survey (NFCS): South Africa 2005. Public Health Nutr 2005:8:533-43.

29. Baxter SD. Self-reports of diet: how children remember what they have eaten. Am J Clin Nutr 1997;65:S1148-52

30. Kaskoun MC, Johnson RK, Goran MI. Comparison of energy intake by semiquantitative food-frequency questionnaire with total energy expenditure by the double labeled water method in young children. Am J Clin Nutr 1994;60:43-7.

31. Livingstone MBE, Robson PJ. Measurement of dietary intake in children. Proc Nutr Soc 2000;59:279-93.

32. Macintyre UE. Dietary intakes of Africans in transition in the North West Province. Potchefstroom. PU for CHO: PhD thesis; 1998

33. Potischman N, Cohen BE, Picciano MF. Dietary recommendations and identified research needs for the National Children's Study. J Nutr 2006;136:686-9.

34. Schröder H, Covas MI, Marrugat J, et al. Use of a three-day estimated food record, a 72-hour recall and a food-frequency questionnaire for dietary assessment in a Mediterranean Spanish population. Clin Nutr 2001;20:429-37.

35. Masson LF, Mcneill G, Tomany J0, et al. Statistical approaches for assessing the relative validity of a foodfrequency: use of correlation coefficients and the kappa statistic. Public Health Nutr 2003;6:313-21.

36. Flood VM, Smith WT, Webb KL, Mitchell P. Issues in assessing the validity of nutrient data obtained from a food-frequency: folate and vitamin B12 examples. Public Health Nutr 2004;7:751-6.

37. Kruger R, Kruger HS, Macintyre UE. The determinants of overweight and obesity among 10-to 15year-old schoolchildren in the North West Province, South Africa- the THUSA BANA (Transition and Health during Urbanization of South Africans; BANA, child) study. Public Health Nutr 2006:9:351-8.

38. Bandini LG, Must A, Cyr H, Anderson SE, Spadano JL, Dietz WH. Longitudinal changes in the accuracy of reported energy intake in girls 10-15 y of age. Am J Clin Nutr 2003;78:480-4.

39. Schoeller DA. How accurate is self-reported dietary energy intake? Nutr Health Rev 1990;48:373-9.

40. Martin LJ, Su W, Jones PJ, Lockwood GA, Tritchler DL, Boyd NF. Comparison of energy intakes determined by food records and doubly labeled water in women participating in a dietary-intervention trial. Am J Clin Nutr 1996;63:483-90.

41. Bandini LG, Schoeller DA, Cyr HN, Dietz WH. Validity of reported energy intake in obese and nonobese adolescents. Am J Clin Nutr 1990;52:421-51.

42. Champagne CM, Baker NB, Delany JP, Harsha DW, Bray GA. Assessment of energy intake underreporting by doubly labeled water observations on reported nutrient intakes in children. J Am Diet Assoc 1998:98:426-30.

43. Green TJ, Allen OB, O'Connor DL. A three-day weighed food record and a semiquantitative foodfrequency questionnaire are valid measures for assessing the folate and vitamin B12 intakes of women aged 16-19 years. J Nutr 1998;128:1665-71.

44. Bratterby L-E, Sandhagen B, Fan H, Enghardt H, Samuelson G. Total energy expenditure and physica activity as assessed by the doubly labeled water method in Swedish adolescents in whom energy intake was under estimated by 7-day diet records. Am J Clin Nutr 1998;67(5);905-11

45. Hise ME, Sullivan DK, Jacobsen DJ, Johnson SL, Donnelly JE. Validation of energy intake measurements determined from observer-recorded food records and recall methods compared with the doubly labeled water method in overweight and obese individuals. Am J Clin Nutr 2002;75:263-7.

46. Bonifacj C, Gerber M, Scali J, Daures JP. Comparison of dietary assessment methods in a Southern French population: use of weighed records, estimated-diet records and a food-frequency questionnaire. Eur J Clin Nutr 1997;51:217-31.

47. Bingham SA, Nelson M, Paul AA, Haraldsdottir J, Bjorge-Loken E, Van Staveren WA. Methods for data collection at an individual level. In: Cameron ME, Van Staveren WA, eds. Manual on methodology for food consumption studies. New York: Oxford University Press; 1988:53-106.

48. Karvetti R, Knuts L. Validity of the estimated food diary: comparison of 2-day recorded and observed food and nutrient intakes. J Am Diet Assoc 1992;92:580-4.
49. Molag ML, De Vries JHM, Ocké MG, et al. Design characteristics of food frequency questionnaires in relation to their validity. Am J Epidemiol 2007;166:1468-78.

50. Mackeown JM, Cleaton-Jones PE, Norris SA. Nutrient intake among a longitudinal group of urban South-African children at four interception between 1995 and 2000 (Birth-to-Ten Study). Nutr Res 2003:23:185-97.

51. Mackeown JM, Perdro TM, Norris SA. Energy, macro- and micronutrient intake among a true longitudina group of South African adolescents at two interceptions (2000 and 2003): the Birth-to-Twenty (Bt20) Study. Public Health Nutr 2007;10(6):635-43.

52. Kono S, Tokui N, Yoshimura, T, Uchioka M, Takewaka H. Review on dietary methods for epidemiologic studies. Sangyo Ika Diagaku Zasshi 1984;6:411-8.

53. Deschamps V, De Lauzon-Buillian B, Lafay L, Borys J-M, Charles MA, Romon M. Reproducibility and relative validity of a food frequency questionnaire among French adults and adolescents. Eur J Clin Nutr 2009;63(2):282-91

54. Matthys C, Pynaert I, De Keyzer W, De Henauw S. Validity and reproducibility of an adolescent web-based food frequency questionnaire. J Am Diet Assoc 2007;107:605-10.

55. Hong TK, Dibley MJ, Sibbritt DW. Validity and reliability of an FFQ for use with adolescents in Ho Chi Minh City, Vietnam. Public Health Nutr 2009:13(3):368-75

56. Taylor C, Lamparello B, Kruczek K, Anderson EJ, Hubbard J, Misra M. Validation of a food frequency questionnaire for determining calcium and vitamin $\mathrm{D}$ intake by adolescent girls with anorexia nervosa. $J$ Am Diet Assoc 2009;109:479-85.

57. Watson JF, Collis CE, Sibbrit DW, Dibley MJ, Garg ML. Reproducibility and comparative validity of a food frequency questionnaire for Australian children and adolescents. Int J Behav Nutr Phys Act 2009:6:62-80.

58. Cade J, Thompson R, Burley V, Warm D. Development, validation and utilisation of food-frequency questionnaires - a review. Pub Health Nutr. 2002;5:567-87.

59. Willet WC. Food frequency methods. In: Willet WC, ed. Nutritional Epidemiology, 2nd ed. New York: Oxford University Press; 74-94.

60. Lietz G, Barton KL, Longbottom PJ, Anderson AS. Can the EPIC food-frequency questionnaire be used in adolescent populations? Pub Health Nutr 2002;5:783-9.

61. Robinson S, Skelton R, Barker M, Wilman C. Assessing the diet of adolescent girls in the UK. Pub Health Nutr 1999;2(4):571-7.

62. Frank GC, Nicklas TA, Webber LS, Major C, Miller JF, Berenson GS. A food frequency questionnaire for adolescents: defining eating patterns. J Am Diet Assoc 1992:92(3):313-8.

63. Rockett HR, Wolf AM, Colditz GA. Development and reproducibility of a food frequency questionnaire to assess diets of older children and adolescents. J Am Diet Assoc 1995;95:336-340.

64. Nelson MC, Lytle LA. Development and evaluation of a brief screener to estimate fast-food and beverage consumption among adolescents. J Am Diet Assoc 2009;109:730-4

65. Macintyre UE, Venter CS, Vorster HH. A culture-sensitive quantitative food frequency questionnaire used in an African population: 2. Relative validation by 7-day weighed records and biomarkers. Public Health Nutr 2001;4:53-62

66. Wiehl DG. Diets of a group of aircraft workers in Southern California. Milbank Memorial Fund Quarterly 1942;20:329-66

67. Baxter SD, Smith AF, Nichols MD, Guinn CH, Hardin JW. Children's dietary reporting accuracy over multiple 24-hour recalls varies by body mass index category. Nutr Res 2006;26:241-8.

68. Lytle LA, Glovsky E, Zive M. Validation of 24-hour recalls assisted by food records in third-grade children Am Diet Assoc 1993;93:1431-6

69. Weber JL, Lytle L, Gittelsohn J, et al. Validity of self-reported dietary intake at school meals by American Indian children: the pathways study. J Am Diet Assoc 2004;104:746-52.

70. Jonnalagadda SS, Mitchell DC, Smiciklas-Wright H, et al. Accuracy of energy intake data estimated by a multiple-pass, 24-jour dietary recall technique. J Am Diet Assoc 2000;100:303-8, 311.

71. Koehler KM, Cunningham-Sabo L, Lambert LC, Mccalman R, Skipper BJ, Davis SM. Assessing food selection in a health promotion program: validation of a brief instrument for American Indian children in the southwest United States. J Am Diet Assoc 2000;100:205-11

72. Smith KW, Hoelscher DM, Lytle LA, et al. Reliability and validity of the Child and Adolescent Trial for Cardiovascular Health (CATCH) Food Checklist: a self-report instrument to measure fat and sodium intake by middle school students. J Am Diet Assoc 2001;101:635-42, 647

73. Cullen KW, Watson K, Zakeri I. Relative reliability and validity of the Block Kids Questionnaire among youth aged 10 to 17 years. J Am Diet Assoc 2008;108:862-866

74. Subar AF, Dodd KW, Guenther PM, et al. The food propensity questionnaire: concept, development, and validation for use as a covariate in a model to estimate usual food intake. J Am Diet Assoc 2006;106:1556-63. 